\title{
Exploring dualities of service innovation: implications for service research
}

Lars Witell, Laurel Anderson, Roderick J. Brodie, Maria Colurcio, Bo Edvardsson, Per

Kristensson, Line Lervik-Olsen, Roberta Sebastiani and Tor Wallin Andreassen

\section{Journal Article}

\section{Tweet}

N.B.: When citing this work, cite the original article.

Original Publication:

Lars Witell, Laurel Anderson, Roderick J. Brodie, Maria Colurcio, Bo Edvardsson, Per Kristensson, Line Lervik-Olsen, Roberta Sebastiani and Tor Wallin Andreassen, Exploring dualities of service innovation: implications for service research, Journal of Services Marketing, 2015. 29(6-7), pp.436-441.

http://dx.doi.org/10.1108/JSM-01-2015-0051

Copyright: Emerald: 24 month embargo

http://www.emeraldinsight.com/

Postprint available at: Linköping University Electronic Press

http://urn.kb.se/resolve?urn=urn:nbn:se:liu:diva-125698

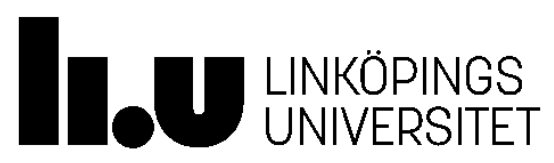




\section{Exploring dualities of service innovation: Implications for}

\section{service research}

\section{INTRODUCTION}

Through a process of creative destruction, innovation can explain and provide a way forward for economic growth (Schumpeter, 1934). Service innovation is dynamic, evolutionary, non-linear, and interactive, but also risky - and without risk no sustainable business would be created. Recent studies highlighted that service innovation occurs in service systems that intersect and overlap at individual (micro), organization (meso), and societal (macro) levels (Chandler \& Vargo, 2011). Perhaps most important, service innovation emphasizes the value-creating processes that occur for the benefitting party. Service innovation creates new opportunities and influences almost everything in our daily lives, but also causes problems for individuals, organizations, and society.

Previous research typically has emphasized the positive effects of service innovation. Rogers (1962) suggests that there is a "pro-change" bias in innovation research, i.e. that customers are open to change and that service innovation leads to more profitable firms and a more efficient public sector. However, while no business leader, consumer, or policy maker is against service innovation, experience has taught us that most new services fail. In fact, nine out of ten new services do not become a commercial success and are withdrawn from the market a year after their launch (Gourville, 2006). The difference between a new service and a service innovation is failure, and understanding failure can help us identifying the key characteristics of service innovation. In addition, new services may have different effects at different 
levels. For example, a new service may be positive for an individual, but the innovator firm may not find a profitable business model, and the new service may have a negative effect on the environment, leading to its rejection. In either case, the new service does not become a service innovation.

We suggest there are dualities in service innovation: (1) A customer can either adopt an innovation or reject it (adopt-reject); (2) an organization may either build a new business model on an innovation or not dare to change its existing business model (change-static); and (3) an innovation may either promote the well-being of individuals or challenge it (good-bad). In this brief essay, we explore these dualities and provide a way for fresh thinking on service innovation in which learning from failures is central.

\section{WHAT IS SERVICE INNOVATION?}

Service innovation has become not only a buzzword, but also a key theoretical concept. Jon Sundbo, Ian Miles and Faïz Gallouj sparked the research interest on service innovation and have continued to develop our understanding of the theoretical concept. Early on, Gallouj and Weinstein (1997) defined service innovation as "Any change affecting one or more terms of one or more vectors of characteristics". From an often technical or characteristics based view of service innovation it now has been complemented with broader perspectives (Coombs \& Miles, 2000). Lusch and Nambisan (2015) suggest that service innovation is "rebundling of diverse resources that create novel resources that are beneficial ... to some actors in a given context." Breaking free from the provider-customer dichotomy enables theories on service innovation to cover new type of services such as social networks (e.g. twitter) and public services (Khan academy) that by a Schumpeterian view is not considered innovations.

Service innovation can be conceptualized and studied from different perspectives, which usually are assimilation, demarcation, and synthesis (Coombs \& Miles, 2000). An 
assimilation perspective views service innovation as the introduction of new technology. A demarcation perspective views service innovation as innovation in the service sector, while a synthesis perspective suggests that all innovations are service innovations. Both the assimilation and synthesis perspectives build on the groundbreaking work of Schumpeter (1934) and the idea that an innovation must contain something new for both the firm and the customer and must be successfully introduced, adopted, and diffused in the market. All three perspectives are reflected in service research. In summary, service innovation can be defined, interpreted, and conceptualized from different perspectives (Coombs \& Miles, 2000). We argue instead of guiding service innovation research, these three perspectives hinder theoretical development. Instead of breaking free from and making new laws, most research papers choose one and follow the laws implied by the chosen perspective.

Previous research has presented dualities of service innovation, most often through the dichotomy of radical and incremental service innovation (Gallouj \& Weinstein, 1997). Witell et al. (2015) identify four such dualities (1) radical incremental, (2) product - process, (3) new to the firm - new to the market, and (4) technology - organization; suggesting that dualities are key to understanding service innovation. For example, a service innovation can result in either saving or spending time: saving time by making a process more effective and allowing it to serve more customers or to analyze data more quickly to help the customer to make better decisions, and spending time by creating an experience put into a game or a show. We suggest that exploring these dualities can inspire fresh thinking on service innovation.

\section{INTRODUCING LEVEL AND OUTCOME TO UNDERSTAND SERVICE INNOVATION}

Service innovation can be understood at the individual, organization, and societal levels. Newness can be understood as "new for the individual," "new to the firm," or 
"new to the world," (e.g. Alam, 2012). This understanding is consistent with viewing service innovation at the micro, meso, or macro levels (Vargo and Lusch, 2014) and gives different perspectives or meanings to the concept. From this perspective, the need emerges for more in-depth investigation of the effects that an innovation may have not only on the individual or the organization, but also on society.

Most research views service innovation from the firm's perspective, based on successful cases such as Apple, Google, IKEA, or Starbucks (e.g. Michel et al., 2008; Rubalcaba et al., 2010). Such studies have been very important for the development of current knowledge on service innovation, but are they sufficient? Often the focus is on the (financial) value created for the firm, rather than the value created for the customer, which is odd, as service marketing is about activities that have value for customers (Day, 1994) or is co-created by them (Vargo and Lusch, 2008). Central to organizations' striving to become customer centric is the dual value process, which is that value should be created both for the customer and the firm (Shah et al., 2006). The key question is whether this one-sided view of successful service innovation can solely advance our knowledge. There is a need to overcome the "pro-change" bias (Rogers, 1962) and investigate failed services, or the missing pieces of the puzzle that may have made a certain service fail.

Service innovation studies often take a snapshot of reality and do not include the mistakes and failures that have been important in the development and diffusion of the service, which may have transformed the service into an innovation. The success of the iPhone and iPad and their relationship to iTunes and the App Store are often used as examples of a successful service innovation and service ecosystem. But what is the role of Newton, the iPad's failed predecessor, or of Microsoft's Tablet PC in 2002? Not unlikely, Apple and Microsoft learned plenty from these failures. Longitudinal studies of 
the service ecosystem and its development might provide answers to how a service innovation evolves over time and how a failure is turned into a success.

\section{EXPLORING DUALITIES OF SERVICE INNOVATION}

To move beyond the traditional view of service innovation and study the topic on different levels of abstraction, we can use the two dimensions introduced in this essay, (1) level (individual, organization, and society) and (2) outcome (success, failure) to identify new research opportunities. These two dimensions reveal three dualities: adopt-reject, change-static, and good-bad (see Figure 1). Most research on service innovation focus on studying service innovation through success in organizations, but moving from this "change" part of the model towards other parts open up new ways to study and theorize on service innovation. Figure 1 includes questions or areas of research that are beneficial to explore for each level and outcome.

Let us look first at service innovation at the individual level: A customer can either adopt or reject a service innovation. Rogers (1962, p. 229) suggested that there is a "prochange" bias in the research, which "assumes that the innovations are "good" and should be adopted by everyone ... Many individuals, for their own good, should not adopt them." Extensive research has used the technology acceptance model (Davis, 1989) or the technology readiness index (Parasuraman, 2000) to examine adoption of technological innovations. Far less is known about adoption or rejection of non-technological innovations, such as experience or social innovations. In particular, lessons can be learned from research into failures-why do customers reject certain new services and adopt others, which then scale up and create a market? For e-services, the key is to create viral loops where each new user is worth more than one more new user. If there is a working business model, such growth will turn a new service into a service innovation. 
Most research on service innovation has concentrated at the firm level on successful services, often including or even focusing on development of a new service (Carlborg et al., 2014) or defining service innovation from a process-based perspective (Gallouj \& Weinstein, 1997). The blurriness of process and output of service innovation is problematic for service research and has made the concept imprecise and hard to operationalize. Service innovation is created through embracing change, but what can we learn from firms that are static and do not change because they do not want to risk a profitable business. Frequently organizations do not begin to innovate until the pressure for change becomes strong. For each firm that succeeds in creating a service innovation, there are several entrepreneurs who fail - and their stories often are not told in service research. We can read about the success of social media sites such as Facebook or even watch the movie, "The Social Network," to learn about the story of Mark Zuckerberg. But, what can we learn from the rise and fall of Eons, Diaspora, and Orkut? Yet these stories that are never told could provide us with significant knowledge about the dos and don'ts of service innovation.

At the societal level, service innovations create new markets or even industries. Lusch and Nambisan (2015) emphasized the role of platforms and ecosystems in shaping the evolution of markets. They argued that all actors are resource integrators, and the roles and processes underlying value co-creation build new ecosystems. Therefore, we can learn from markets that do not work or that fail to turn new services into service innovations. For example, why did financiers and governmental institutions reject entrepreneur Johan Wendt's suggested social service innovation "Center for Mathematics," which today helps 110,000 Swedish children every week with learning math, calling it "the most stupid idea they ever had heard"? 
We could better realize how to activate and coordinate actors in service systems to succeed with new services if we examined not only positive issues, but also the negative ones on all levels - the individual level (such as frustration of adoption, wasting time, unlearning/re-learning), the organizational level (for example, loss of competitive advantage; waste of time, money, and resources; lay-offs), and the societal level (for example, lack of economic growth). However, a service innovation that creates a new market for an organization could at the same time be negative for other organizations. Innovations in the music industry have changed "the rule of the game," which have created winners, but also losers, such as stores that cannot sell CDs or new rock bands that do not make profits on album sales. For the losers, these innovations are bad, resulting in less income and loss of jobs.

- insert Figure 1 about here -

\section{REFLECTIONS}

Service research should find new ways to build knowledge regarding service innovation. Theory development must include general, mid-range, and theories currently in use (Brodie \& Storbacka, 2014). Theory development in service research appears on several levels, but the translation process in both directions is failing, which limits the results to either a general theory that does not work in practice or a theory that is far too contextspecific. Perhaps if the dualities of service innovation were more often considered, we could move service innovation research forward.

Far too many studies focus on the positive side of innovation, neglecting the negative side and the understanding of failures. We maintain that the "pro-change" bias in service innovation research goes beyond the individual level (Rogers, 1962), and extends into the organizational and societal levels. Empirical researchers often find it difficult to identify failures or get good case descriptions of failures, which may 
complicate learning from failures and applying such knowledge to theory development. But, both successes and failures are important sources for learning and theorizing in service innovation research.

Exploring the dualities of service innovation means using research methods based on longitudinal studies of the innovation on several levels (individual, organization and society). It means moving away from studies of the $10 \%$ of the new services that succeed in the market and to explore the $90 \%$ of new services that fail. It also means exploring new dimensions of service innovation that moves beyond technology, business model and experience towards social innovation and behavioral innovation.

One specific dimension of service innovation that deserves more attention is risk, for without risk there is no innovation. For customers, risk is framed as the possibility of making a wrong decision. The natural response is to reject innovations or to be more reluctant to adopt new services. For firms, we know that only one in 10 innovations succeed, and therefore innovation is linked to high risk, loss of firm value, and waste of resources that in the end might ruin the firm's competitive advantage. A firm's natural response to risk is to focus on incremental innovations rather than radical innovations. For society, the risk is allocation of resources to projects with a low return, and thus, using scarce resources incorrectly. The economic, political, and social aspects of risk are central to innovation, and research on service innovation has not sufficiently addressed this issue.

\section{REFERENCES}

Alam, I. (2012). New service development in India's business-to-business financial services sector. Journal of Business \& Industrial Marketing, 27(3), 228-241. 
Brodie, R. J., \& Storbacka, K. (2014). Collaborative theorising about markets and marketing and service-dominant logic. Marketing Theory, 14(3), 231-237.

Carlborg, P., Kindström, D., \& Kowalkowski, C. (2014). The evolution of service innovation research: A critical review and synthesis. Service Industries Journal, 34(5), 373-398.

Chandler, J.D. and Vargo, S.L. (2011). Contextualization and Value-in-Context: How Context Frames Exchange. Marketing Theory, 11(1), 35-49.

Coombs, R., \& Miles, I. (2000). Innovation, measurement, and services: The new problematique. In J. S. Metcalfe \& I. Miles (Eds.), Innovation systems in the service economy, economics of science, technology, and innovation, pp. 83-102. Dordrecht: Kluwer.

Davis, F. D. (1989). Perceived usefulness, perceived ease of use, and user acceptance of information technology, MIS Quarterly, 13(3), 319-340.

Day, G. S. (1994). The Capabilities of Market-Driven Organizations, Journal of Marketing, $58(4), 37-52$.

Gallouj, F., \& Weinstein, O. (1997). Innovation in services. Research Policy, 26, 537-556.

Gourville, J. T. (2006). Eager sellers, stony buyers. Harvard Business Review, 84(6), 99106.

Lusch, R. F., \& Nambisan, S. (2015). Service innovation: A service-dominant logic perspective. MIS Quarterly, 39(1), 155-176.

Michel, S., Brown, S. W., \& Gallan, A. S. (2008). Service-logic innovations: How to innovate customers, not products. California Management Review, 50, 49-65.

Parasuraman, A. (2000). Technology readiness index (TRI): A multiple-item scale to measure readiness to embrace new technologies. Journal of Service Research, 2(4), $307-320$. 
Rogers, E.M. (1962). Diffusion of Innovations. The Free Press, New York.

Rubalcaba, L., Michel, S., Sundbo, J., Brown, S. W., \& Reynoso, J. (2012). Shaping, organizing, and rethinking service innovation: A multidimensional framework. Journal of Service Management, 23(5), 696-715.

Schumpeter, J. A. (1934). The theory of economic development: An inquiry into profits, capital, credit, interest, and the business cycle. Cambridge, Massachusetts: Harvard University Press.

Shah, D. S., Rust, R. T., Staelin, R., \& Day, G. S. (2006). The path to customer centricity. Journal of Service Research, 9(2), 113-124.

Vargo, S. L., \& Lusch, R. F. (2008). Service-dominant logic: Continuing the evolution. Journal of Academy of Marketing Science, 36, 1-10.

Vargo, S. L., \& Lusch, R. F. (2014). Service-Dominant Logic: Premises, Perspectives, Possibilities. Cambridge University Press, Cambridge.

Witell, L., Snyder, H, Gustafson, A., Fombelle, P., \& Kristensson, P. (2015). Identifying categories of service innovation: A review and synthesis of the literature. Forthcoming in Journal of Business Research. 


\section{Tables and Figures}

Figure 1: The focus of research on service innovation

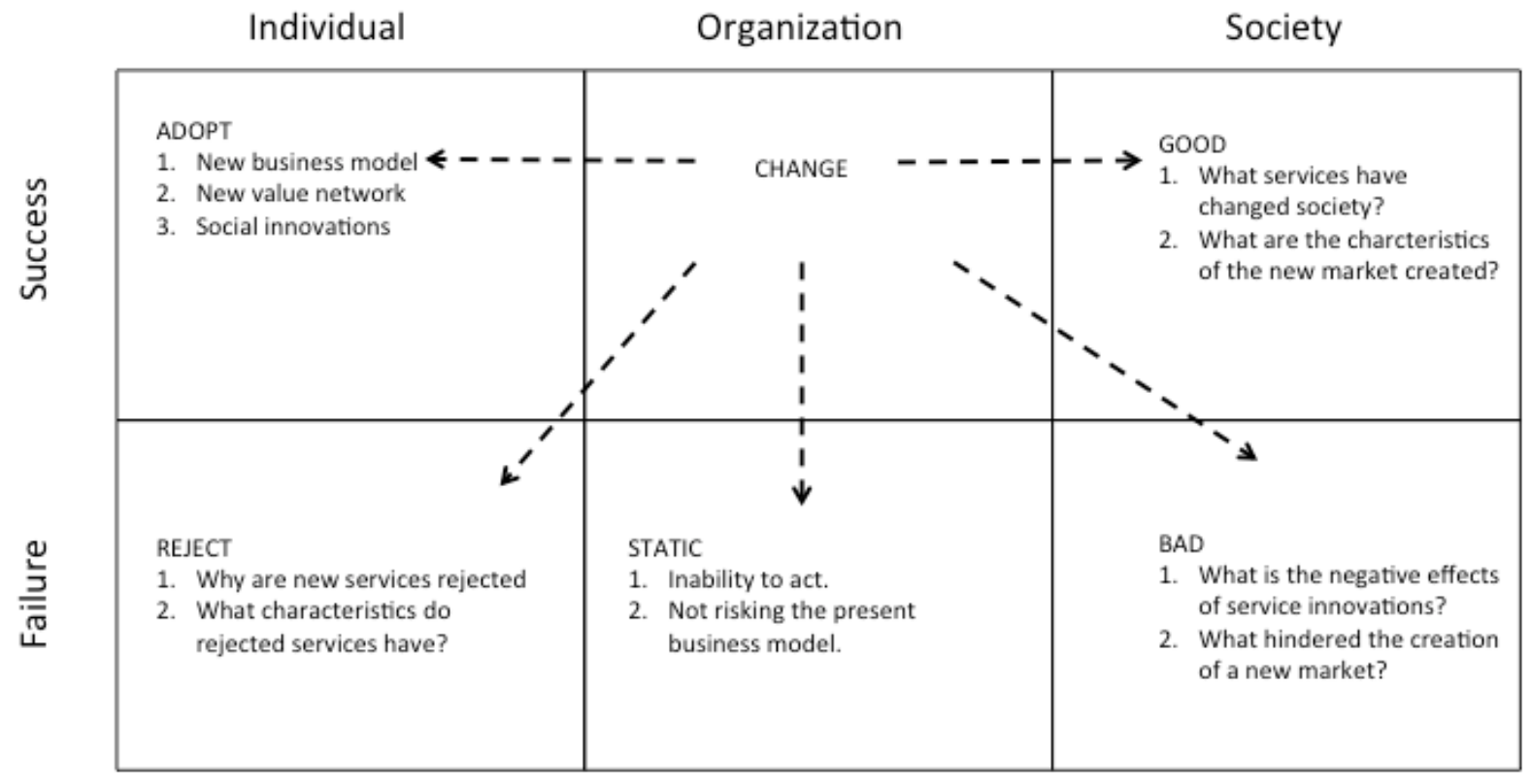

